\title{
PERENCANAAN KARIER SISWA DI SMA DITINJAU DARI STATUS SOSIAL EKONOMI, JENIS KELAMIN, DAN JURUSAN
}

\author{
Heni Sulusyawati \\ Universitas Negeri Padang \\ A. Muri Yusuf \\ Universitas Negeri Padang \\ Daharnis \\ Universitas Negeri Padang
}

\begin{abstract}
Abstrak
Penelitian ini dilatarbelakangi oleh masih ditemukan siswa yang belum memiliki tujuan dan rencana karier yang jelas. Tujuan dari penelitian ini adalah (1) mendeskripsikan perencanaan karier siswa ditinjau dari status sosial ekonomi, jenis kelamin, dan jurusan, (2) menguji perbedaan perencanaan karier siswa ditinjau dari status sosial ekonomi tinggi, sedang, dan rendah, (3) menguji perbedaan perencanaan karier siswa ditinjau dari jenis kelamin laki-laki dan perempuan, (4) menguji perbedaan perencanaan karier siswa ditinjau dari jurusan IPA dan IPS, (5) menguji perbedaan perencanaan karier siswa ditinjau dari interaksi antara status sosial ekonomi, jenis kelamin, dan jurusan. Penelitian ini merupakan penelitian deskriptif komparatif dengan menggunakan desain faktorial $2 \times 2 \times 3$. Populasi penelitian adalah siswakelas XI SMANegeri 7 Padang yang berjumlah 258 siswa. Jumlah sampel sebanyak 160 orang yang dipilih dengan teknik proportional random sampling. Instrumen yang digunakan adalah skala perencanaan karier dengan nilai reliabilitas sebesar 0,751. Data dianalisis dengan menggunakan statistik deskriptif dan Analysis of Variance (ANOVA).Hasil penelitian menunjukkan bahwa: (1) perencanaan karier siswa ditinjau dari status sosial ekonomi, jenis kelamin, dan jurusan berada pada kategori tinggi, (2) tidak terdapat perbedaan yang signifikan perencanaan karier siswa ditinjau dari status sosial ekonomi tinggi, sedang, dan rendah, (3) tidak terdapat perbedaan yang signifikan perencanaan karier siswa ditinjau dari kelamin laki-laki dan perempuan, (4) tidak terdapat perbedaan yang signifikan perencanaan karier siswa ditinjau dari jurusan IPA dan IPS, (5) tidak terdapat perbedaan perencanaan karier siswa ditinjau dari interaksi antara status sosial ekonomi, jenis kelamin, dan jurusan. Implikasi dari hasil penelitian ini adalah sebagai salah satu bahan masukan dalam membuat program layanan bimbingan dan konseling, terutama dalam perencanaan karier.
\end{abstract}

Kata Kunci: Perencanaan Karier, Status Sosial Ekonomi, Jenis Kelamin, Jurusan.

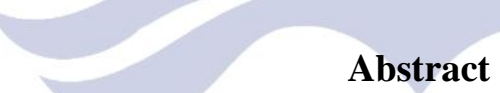

The background of this research was motivated by there were students who have not the goal and a clear career plan. The purpose of this study were (1) describe students career planning is sighted socio-economic status, gender, and majors, (2) examined differences in students career planning of socio-economic status of high, medium, and low, (3) examined differences in students career planning of based on male and female, (4) examined differences in students career planning majoring in science and social studies, (5) examined differences in career planning of students based on interaction of between socio-economic status, gender, and majors. This research is a comparative descriptive study using $2 \times 2 \times 3$ factorial design. The population of this research was a class XI students at SMAN 7 Padang with 258 students. Sample this research consistsof 160 people and selected by proportional random sampling technique. The instrument was using career planning scale reliability value of 0,751 . Data were analyzed using descriptive statistics and Analysis of Variance (ANOVA). The results showed that: (1) students career planning in terms of socio-economic status, gender, and majors at the high category, (2) there is no significant differences in career planning of

students in terms of socio-economic status of high, medium and low, (3) there is no significant differences in career planning of students in terms of male and female, (4) there is no

significant difference in career planning of students in terms of majoring in science and social studies, (5) there is no difference in career planning of students in terms of interaction between socio-economic status, gender, and majors. The implication of this research as one of an input for designing aguidance and counseling program, especially in the career planning.

Keywords: Career Planning, Socio-Economic Status, Gender, Majors 


\section{PENDAHULUAN}

Perencanaan karier merupakan hal yang sangat penting bagi siswa dalam mencapai sukses karier.Semua siswa menginginkan sukses dalam karier; agar siswa dapat sukses dalam karier diharapkan siswa dapat merencanakan kariernya, karena sukses dalam karier diawali dengan perencanaan karier yang baik.Karier bukan hanya job dan bukan pula okupasi, tetapi karier merupakan suatu rangkaian pekerjaan seseorang selama hidupnya (Yusuf, 2002:28).

Mengingat perencanaan karier merupakan awal bagi siswa dalam mencapai sukses karier, maka diharapkan siswa dapat menyelesaikan tugas-tugas perkembangan karier sesuai dengan tahap perkembangan karier.Super (dalamSharf, 2010) mengemukakan proses perkembangan karier dibagi atas lima tahap yaitu: tahap pengembangan (growth) dari saat lahir sampai sebelum umur15 tahun, tahap eksplorasi (exploration) dari umur 15 sampai 25 tahun, tahap pemantapan (establishment) antara umur 25 sampai 45 tahun, tahap pembinaan (maintenance) umur 45 tahun sampai 65 tahun, tahap (decline) sekitar umur 65 tahun, individu sudah memasuki masa pensiun dan harus menemukan pola hidup baru sesudah melepaskan jabatannya. Kelima tahap tersebut dipandang sebagai acuan bagi munculnya sikap-sikap dan perilaku yang menyangkut keterlibatan dalam suatu jabatan, yang tampak dalam tugas-tugas perkembangan karier.

Super (dalamWinkel\& Hastuti, 2013:632) mengemukakan bahwa tugas-tugas perkembangan karier individu dibagi atas empat tahap yaitu: perencanaan garis besar masa depan (crystallization) antara umur 1418tahun, yang bersifat kognitif dengan meninjau diri sendiri dan situasi hidupnya. Penentuan (specification) antara umur 18-24 tahun, yang bercirikan mengarahkan diri ke bidang jabatan tertentu dan mulai memegang jabatan itu. Pemantapan (establishment) antara umur 2435 tahun, yang bercirikan membuktikan diri mampu memangku jabatan yang terpilih. Pengakaran (consolidation) sesudah umur 35 tahun sampai masa pensiun, yang bercirikan mencapai status tertentu dan memperoleh senioritas.

Berdasarkan tahap di atas, tahap pengembangan (growth) merupakan awal dimana siswa mengembangkan berbagai potensi, namun belum/spesifik. Siswa SMA berada pada rentang usia 15-18 tahun yang merupakan tahap eksplorasi (exploration) yang ditandai dengan individu memikirkan berbagai alternatif jabatan, tetapi belum mengambil keputusan yang mantap. Pre-okupasi di SMA sudah dimulai namun dapat berubah karena beberapa faktor yang mempengaruhi perencanaan karier. Ginzberg (dalam Winkel \& Hastuti, 2013:628) mengemukakan bahwa pada umur 17 tahun sampai kurang dari 25 tahun individu barada pada tahap realistis, individu akan melalui tiga sub tahapan, yaitu: 1)tahap eksplorasi (exploration) di mana individu mempertimbangkan dua atau tiga alternatif jawaban, tetapi belum dapat mengambil keputusan, 2) tahap pemantapan (chrystallization) di mana orang muda mulai merasa lebih mantap kalau memangku jabatan tertentu, 3) tahap penentuan (specification) di mana orang mudah mengambil keputusan tentang jabatan tertentu.

Mengingat karier merupakan aspek-aspek tugas perkembangan, maka hal ini sangat penting dan harus dicapai oleh siswa. Melalui aspek perkembangan karier ini siswa paham tentang jenis pekerjaan, yang akan mempengaruhi kesungguhannya dalam belajar. Selanjutnya, dapat meningkatkan keahlian yang dimiliki, dan akan memudahkan siswa dalam perencanaan karier. Hal inilah yang menjadi pertimbangan bagisiswa dalam mengambil keputusan karier.

Melalui pendidikan formal siswa dapat merencanakan kariernya, karena pendidikan merupakan suatu proses agar seseorang memperoleh pengetahuan, pemahaman, dan cara bertingkah laku yang baiksesuai dengan apa yang diharapkan oleh tujuan pendidikan itu sendiri.Dijelaskan dalam Undang-undang Sistem Pendidikan Nasional Nomor20 Tahun 2003.

Yusuf (2002:59) mengemukakan dunia pendidikan merupakan masa pre-okupasi, dan memasuki pensiun merupakan masa post-okupasi.Sebagai suatu sistem, masa pre-okupasi, okupasi dan masa post-okupasi hendaknya menyatu dalam kehidupan seseorang sehingga sukses karier merupakan suatu rentang keberhasilan dalam tiga "dunia".

Dunia pendidikan adalah awal yang ikut menentukan perencanaan karier siswa. Walaupun siswa belum dapat melakukan perencanaan pekerjaan pada saat mereka memasuki SMA, namun tidak dapat dihindari bahwa pendidikan memiliki peran penting dalam membantu siswa mengenal berbagai potensi yang ada di dalam dirinya. Dunia pendidikan dapat menyediakan berbagai informasi karier kepada siswa karena informasi karier sangat penting bagi siswa dalam perencanaan karier.

Mengingat informasi karier bagi siswa sangat penting dalam perencanaan karier, maka diharapkan peran bimbingan dan konseling di sekolah dapat membantu siswa. Guru bimbingan dan konseling di sekolah diharapkan dapat memberikan berbagai layanan terkait dengan perencanaan karier siswa. Aspek yang sangat penting untuk dikembangkan dalam perencanaan karier siswa adalahkemampuan memahami dirinya, mengenal dunia kerja, dan merencanakan masa depan yang sesuai dengan bentuk kehidupan yang diharapkannya, menentukan dan mengambil keputusan yang tepat serta bertanggung jawab, sehingga mampu mewujudkan diri yang bermakna.

Pelayanan bimbingan dan konseling di sekolah memiliki peran penting dalam membantu siswa merencanakan kariernya.Menurut Ahmad (2013:73) perencanaan karier tertentu telah dimulai sejak seseorang berada di bangku sekolah. Pelayanan bimbingan dan konseling seyogyanya memberikan layanan dalam bentuk penyediaan peluang bagi dikenalnya berbagai karier oleh siswa, mempersiapkan diri untuk suatu karier serta merencanakan karier masa depan.

Agar bimbingan dan konseling di sekolah dapat berjalan dengan baik dalam membantu siswa merencanakan kariernya, maka perlu diketahui faktorfaktor yang mempengaruhi perencanaan karier siswa.Winkel \& Hastuti (2013:647) mengemukakan faktor-faktor yang mempengaruhi perencanaan karier 
yaitu nilai-nilai kehidupan(values), inteligensi, bakat khusus, minat, sifat-sifat, pengetahuan, keadaan jasmani, masyarakat, keadaan sosialekonomi negara atau daerah, status sosial ekonomi keluarga, pengaruh anggota keluarga, pendidikan sekolah, pergaulan dengan teman sebaya, dan tuntutan yang melekat pada masing-masing jabatan.

Berdasarkan penjelasan sebelumnya, dapat dilihat bahwa status sosial ekonomi keluarga ikut menentukan perencanaan karier siswa.Hal ini dapat dilihat dari tingkat pendidikan orangtua dan tinggi rendahnya pendapatan orangtua serta daerah tempat tinggal. Faktor lain adalah dapat dilihat dari jenis kelamin.

Hurlock (1996) mengemukakan bahwa "Anak SMAmulai memikirkan masa depansecara bersungguhsungguh. Anak laki-lakilebih bersungguhsungguhdalamhal pekerjaan dibandingkan dengan anak perempuan".

Berdasarkan penjelasan di atas, dikatakan bahwa anak laki-laki dan anak perempuan dalam merencanakan kariernya tidak sama, anak laki-laki lebih serius merencanakan kariernya bila dibandingkan dengan anak perempuan karena anak laki-laki akan bertanggung jawab terhadap keluarganya. Sementara anak perempuan tidak memiliki tanggung jawab penuh terhadap keluarga.

Berdasarkan studi pendahuluan yang dilakukan pada hari Jum'at tanggal 8 Mei 2015 di Sekolah Menengah Atas (SMA) Negeri 7 Padang melalui wawancara, ditemukan siswa yang belumserius dalam merencanakan kariernya, masih kurangnya pemahaman siswa tentang informasi karier, masih ditemukan siswa belum memiliki perencanaan karier setelah tamat SMA, masih ditemukan siswa yang mengalami kebingungan dalam menentukan jenis pendidikan lanjutan yang akan ditempuhnya dalam prospek pekerjaan atau jabatan jika mereka menyelesaikan studinya, siswa perempuan lebih serius dalam mempersiapkankariernya bila dibandingkan dengan siswa laki-laki.Hal ini dilihat dari semangat belajar siswa perempuan lebih tinggi dari pada siswa laki-laki, masih kurang optimalnya peran bimbingan dan konseling untuk membantu siswa dalam perencanaan karier.

Fenomena lainnya adalah berdasarkan data awal yang peneliti dapatkan melalui wawancara di SMA Negeri 7 Padang, peneliti menemukan bahwa data status sosial ekonomi keluarga siswa yang berbeda, ditinjau dari pekerjaan orangtua siswa ada yang pegawai negeri sipil (PNS), wiraswasta, buruh, dagang, dan nelayan. Jika ditinjau dari pendapatan orangtua juga berbeda berkisar dari pendapatan lima ratus ribu sampai lima juta rupiah perbulan, dan pendidikan orangtua yang berbeda mulai dari Sekolah Dasar (SD) sampai Doktor.

Peneliti juga menemukan terdapat dua jurusan yang ada di SMA Negeri 7Padang yaitu jurusan Ilmu Pengetahuan Alam (IPA) dan jurusan Ilmu Pengetahuan Sosial (IPS), kedua jurusan ini tentu sangat berbeda. Berdasarkan faktor budaya masih ada guru beranggapan bahwa jurusan IPA lebih bagus dari pada jurusan IPS, hal itu tentu berpengaruh terhadap siswa dalam merencanakan karier, masih ditemukan siswa jurusan IPA belum tahu untuk mengambil jurusan di Perguruan Tinggi, begitu juga dengan siswa jurusan IPS. Sementara yang diharapkan siswa setelah tamat SMA dapat melanjutkan pendidikan ke Perguruan Tinggi sesuai dengan jurusan yang dipilih ketika di SMA, maka dari itu berdasarkan analisis kebutuhan perlu untuk diketahui apakah berbeda siswa jurusan IPA dan siswa Jurusan IPS dalam merencanakan karier.

Hasil penelitian Zen (2012)menunjukkan bahwa, terdapat pengaruhlangsung $2,99 \%$ dan tidak langsung $0,53 \%$ status sosial ekonomi terhadap perencanaan karier.Menurut hasil penelitian ini dapat diambil kesimpulan bahwa secara langsung maupun tidak langsung status sosial ekonomi keluarga berpengaruh terhadap perencanaan kariernya.Hasil penelitian Megan C. Hoffman (2007) menunjukkan bahwa siswa yang status sosial ekonominya rendah lebih kecil kemungkinannya untuk merencanakan karier.

Berdasarkan peran bimbingan dan konseling di sekolah, faktor-faktor yang mempengaruhi perencanaan karier siswa, fenomena di lapangan dan hasil penelitian di atas, maka perlu didalami bagaimana gambaran perencanaan karier siswa.Hal itulah yang mendorong peneliti untuk melakukan penelitian dengan judul "Perencanaan Karier Siswa di SMA Ditinjau dari Status Sosial Ekonomi, Jenis Kelamin dan Jurusan".

Tujuan penelitian ini yaitu: (1) mendeskripsikan perencanaan karier siswa secara keseluruhan, (2) menguji perbedaan perencanaan karier siswa ditinjau dari status sosial ekonomi tinggi, sedang, dan rendah, (3) menguji perbedaan perencanaan karier siswa ditinjau dari jenis kelamin laki-laki dan perempuan, (4) menguji perbedaan perencanaan karier siswa ditinjau dari jurusan IPA dan IPS, (5) menguji perbedaan perencanaan karier siswa ditinjau dari interaksi antara status sosial ekonomi, jenis kelamin, dan jurusan.

\section{METODOLOGI}

Penelitian ini menggunakan pendekatan kuntitatif. Penelitian akan mendeskripsikan perencanaan karier siswa di SMA ditinjau dari status sosial ekonomi, jenis kelamin, dan jurusan. Selain deskriptif, juga dilakukan studi komparatif yang bertujuan membandingkan data yang diperoleh dari kelompok yang ada.Metode penelitian yang dipakai adalahex post facto dengan desain faktorial $2 \times 2 \times$ 3.

Populasi dalam penelitian ini adalah siswa SMA Negeri 7 Padang sebanyak 268 orang, sampel berjumlah 160 orang,yang dipilih dengan teknik proportionalrandom sampling. Instrumen yang digunakan adalah model skala Likert.Instrumen penelitian ini telahlulus validasi dari beberapa ahli dan juga lulus uji reliabilitas di lapangan. Pengujian hipotesis dengan menggunakan teknik Analysis of Variance (ANOVA), sebelum pengujian hipotesis telah dilaksanakan pengujian persyaratan analisis yaitu uji homogenitas dan uji normalitas.

\section{HASIL PENELITIAN}

Deskripsi data perencanaan karier siswa ditinjau dari status sosial ekonomi, jenis kelamin dan jurusan dapat dilihat pada Tabel 1 .

Tabel 1. Perencanaan Karier Siswa Ditinjau dari Status Sosial Ekonomi, Jenis Kelamin dan Jurusan 


\begin{tabular}{|c|c|c|c|c|c|c|}
\hline Jurusan & $\begin{array}{c}\text { Jenis } \\
\text { Kelamin }\end{array}$ & $\begin{array}{c}\text { Status } \\
\text { Sosial } \\
\text { Ekonomi }\end{array}$ & $\mathrm{N}$ & Mean & $\mathrm{Sd}$ & $\begin{array}{c}\mathrm{Ke} \\
\mathrm{t}\end{array}$ \\
\hline \multirow[t]{12}{*}{ IPA } & \multirow[t]{4}{*}{ Laki-laki } & Tinggi & 17 & 132,29 & 11,29 & $\mathrm{~T}$ \\
\hline & & Sedang & 11 & 137,18 & 13,02 & $\mathrm{~T}$ \\
\hline & & Rendah & 8 & 141,88 & 14,16 & ST \\
\hline & & Total & 36 & 135,92 & 12,72 & $\mathrm{~T}$ \\
\hline & \multirow{4}{*}{$\begin{array}{c}\text { Perempu } \\
\text { an }\end{array}$} & Tinggi & 21 & 128,43 & 13,58 & $\mathrm{~T}$ \\
\hline & & Sedang & 29 & 129,66 & 17,35 & $\mathrm{~T}$ \\
\hline & & Rendah & 24 & 138,21 & 11,78 & $\mathrm{~T}$ \\
\hline & & Total & 74 & 132,08 & 15,11 & $\mathrm{~T}$ \\
\hline & \multirow[t]{4}{*}{ Total } & Tinggi & 38 & 130,16 & 12,29 & $\mathrm{~T}$ \\
\hline & & Sedang & 40 & 131,72 & 16,47 & $\mathrm{~T}$ \\
\hline & & Rendah & 32 & 139,13 & 12,28 & $\mathrm{~T}$ \\
\hline & & Total & 110 & 133,34 & 14,42 & $\mathrm{~T}$ \\
\hline \multirow[t]{12}{*}{ IPS } & \multirow[t]{4}{*}{ Laki-laki } & Tinggi & 11 & 128,91 & 10,40 & $\mathrm{~T}$ \\
\hline & & Sedang & 4 & 117,25 & 15,30 & $\mathrm{~T}$ \\
\hline & & Rendah & 14 & 136,36 & 15,66 & $\mathrm{~T}$ \\
\hline & & Total & 29 & 130,90 & 14,86 & $\mathrm{~T}$ \\
\hline & \multirow{4}{*}{$\begin{array}{l}\text { Perempu } \\
\text { an }\end{array}$} & Tinggi & 4 & 138,50 & 9,32 & $\mathrm{~T}$ \\
\hline & & Sedang & 7 & 132,14 & 23,24 & $\mathrm{~T}$ \\
\hline & & Rendah & 10 & 130,70 & 23,42 & $\mathrm{~T}$ \\
\hline & & Total & 21 & 132,67 & 20,75 & $\mathrm{~T}$ \\
\hline & \multirow[t]{4}{*}{ Total } & Tinggi & 15 & 131,47 & 10,73 & $\mathrm{~T}$ \\
\hline & & Sedang & 11 & 126,73 & 21,23 & $\mathrm{~T}$ \\
\hline & & Rendah & 24 & 134,00 & 19,01 & $\mathrm{~T}$ \\
\hline & & Total & 50 & 131,64 & 17,40 & $\mathrm{~T}$ \\
\hline \multirow[t]{12}{*}{ Total } & \multirow[t]{4}{*}{ Laki-laki } & Tinggi & 28 & 130,96 & 10,88 & $\mathrm{~T}$ \\
\hline & & Sedang & 15 & 131,87 & 15,95 & $\mathrm{~T}$ \\
\hline & & Rendah & 22 & 138,36 & 15,04 & $\mathrm{~T}$ \\
\hline & & Total & 65 & 133,68 & 13,83 & $\mathrm{~T}$ \\
\hline & \multirow{4}{*}{$\begin{array}{c}\text { Perempu } \\
\text { an }\end{array}$} & Tinggi & 25 & 130,04 & 13,37 & $\mathrm{~T}$ \\
\hline & & Sedang & 36 & 130,14 & 18,29 & $\mathrm{~T}$ \\
\hline & & Rendah & 34 & 136,00 & 16,07 & $\mathrm{~T}$ \\
\hline & & Total & 95 & 132,21 & 16,40 & $\mathrm{~T}$ \\
\hline & \multirow[t]{4}{*}{ Total } & Tinggi & 53 & 130,53 & 12,01 & $\mathrm{~T}$ \\
\hline & & Sedang & 51 & 130,65 & 17,49 & $\mathrm{~T}$ \\
\hline & & Rendah & 56 & 136,93 & 15,58 & $\mathrm{~T}$ \\
\hline & & Total & 160 & 132,81 & 15,38 & $\mathrm{~T}$ \\
\hline
\end{tabular}

Berdasarkan Tabel 1, dapat dilihat perencanaan karier siswa ditinjau dari status sosial ekonomi, jenis kelamin, dan jurusan secara keseluruhan berada pada kategori tinggi (T). Hal itu dapat dilihat dari rata-rata skor (mean) perencanaan karier yang paling tinggi adalah siswa lakilaki jurusan IPA dengan status sosial ekonomi rendah dengan rata-rata skor (mean) 141,88 dan skor (mean) perencanaan karier yang terendah adalah siswa laki-laki jurusan IPS dengan status sosial ekonomi sedang, dengan rata-rata skor (mean) 117,25. Selanjutnya, dari Tabel 1 juga dapat dilihat rata-rata skor (mean) perencanaan karier siswa ditinjau dari status sosial ekonomi, jenis kelamin, dan jurusan dari yang tertinggi sampai dengan yang terendah, yaitu:

a. Siswa laki-laki jurusan IPA status sosial ekonomi rendah $(141,88)$.

b. Siswa perempuan jurusan IPS status sosial ekonomi tinggi $(138,50)$.

c. Siswa perempuan jurusan IPA status sosial ekonomi rendah $(138,21)$.

d. Siswa laki-laki jurusan IPA status sosial ekonomi sedang $(137,18)$.

e. Siswa laki-laki jurusan IPS status sosial ekonomi rendah (136,36).

f. Siswa laki-laki jurusan IPA status sosial ekonomi tinggi $(132,29)$. g. Siswa perempuan jurusan IPS status sosial ekonomi sedang $(132,14)$.

h. Siswa perempuan jurusan IPS status sosial ekonomi rendah $(130,70)$.

i. Siswa perempuan jurusan IPA status sosial ekonomi sedang $(129,66)$.

j. Siswa laki-laki jurusan IPS status sosial ekonomi tinggi $(128,91)$.

k. Siswa perempuan jurusan IPA status sosial ekonomi tinggi $(128,43)$.

1. Siswa laki-laki jurusan IPS status sosial ekonomi sedang $(117,25)$.

Secara keseluruhan rata-rata (mean) skor perencanaan karier siswa ditinjau dari status sosial ekonomi, jenis kelamin dan jurusan dengan desain faktorial $2 \times 2 \times 3$ dapat dilihat pada Tabel 2.

Tabel 2. Rata-rata (mean) skor perencanaan karier siswa ditinjau dari status sosial ekonomi, jenis kelamin, dan jurusan dengan desain faktorial $2 \times 2 \times 3$

\begin{tabular}{|c|l|c|c|c|c|}
\hline \multirow{2}{*}{ Jurusan } & \multirow{2}{*}{$\begin{array}{l}\text { Jenis } \\
\text { Kelamin }\end{array}$} & \multicolumn{3}{|c|}{ Status Sosial Ekonomi } & \multirow{2}{*}{$\sum$} \\
\cline { 3 - 5 } & Tinggi & Sedang & Rendah & \\
\hline \multirow{2}{*}{ IPA } & Laki-laki & 132,29 & 137,18 & 141,88 & 135,92 \\
& & & & & \\
\cline { 3 - 5 } & Perempuan & 128,43 & 129,66 & 138,21 & 132,08 \\
\hline \multirow{2}{*}{ IPS } & Laki-laki & 128,91 & 117,25 & 136,36 & 130,90 \\
\cline { 3 - 5 } & Perempuan & 138,50 & 132,14 & 130,70 & 132,67 \\
\hline & & 130,53 & 130,65 & 136,93 & 132,81 \\
\hline
\end{tabular}

Pengujian hipotesis dilakukan dengan teknik Analysis of Variance (ANOVA), hasil pengujian hipotesis dapat dilihat pada Tabel 3.

Tabel 3.Ringkasan Analysis of Variance (ANOVA) Faktorial 3 Jalur

\begin{tabular}{|l|l|l|l|l|l|}
\hline Sumber Variansi & $\begin{array}{l}\text { Sum of } \\
\text { Square }\end{array}$ & Df & $\begin{array}{l}\text { Mean } \\
\text { Square }\end{array}$ & F & Sig \\
\hline $\begin{array}{l}\text { Status Sosial } \\
\text { Ekonomi }\end{array}$ & $\begin{array}{l}1186,77 \\
5\end{array}$ & 2 & 593,388 & 2,593 & 0,078 \\
\hline Jenis Kelamin & 10,889 & 1 & 10,889 & 0,048 & 0,828 \\
\hline Jurusan & 433,901 & 1 & 433,901 & 1,896 & 0,171 \\
\hline $\begin{array}{l}\text { Interaksi } \\
\begin{array}{l}\text { Variabel Status } \\
\text { Sosial Ekonomi, }\end{array}\end{array}$ & & & & \\
$\begin{array}{l}\text { Jenis Kelamin, } \\
\text { dan Jurusan }\end{array}$ & 747,572 & 2 & 373,786 & 1,633 & 0,199 \\
\hline
\end{tabular}

Berdasarkan kriteria pengujian hipotesis, maka dapat ditarik kesimpulan tidak terdapat perbedaan perencanaan karier siswa ditinjau dari status sosial ekonomi, jenis kelamin, dan jurusan baik secara sendiri-sendiri maupun secara bersama-sama.

\section{PEMBAHASAN}

\section{Gambaran Perencanaan Karier Siswa}


Hasil analisis deskriptif menunjukkan bahwa secara keseluruhan perencanaan karier siswa ditinjau dari status sosial ekonomi, jenis kelamin, dan jurusan tergolong tinggi.Artinya siswa sudah paham tentang kondisi diri, paham tentang informasi dunia kerja, dan mampu menyelaraskan antara kondisi diri dengan pengetahuan tentang dunia kerja, sehingga siswa dapat merencanakan karier yang diinginkan sesuai dengan kondisi diri Person (dalam Brown, 2002).Hal ini menunjukkan bahwa perencanaan karier penting bagi siswa dalam mencapai sukses karier.

1. Perbedaan Perencanaan Karier Siswa Ditinjau dari Status Sosial Ekonomi Tinggi, Sedang, dan Rendah serta Perbedaannya

Hasil analisis data menunjukkan bahwa perencanaan karier siswa dari status sosial ekonomi tinggi, sedang, dan rendah tergolong dalam kategori tinggi (T).Jika dilihat dari rata-rata masing-masing status sosial ekonomi, perencanaan karier siswa dari status ekonomi tinggi lebih tinggi perencanaan kariernya dibandingkan dengan siswa dari status sosial ekonomi sedang, begitu juga siswa dari status sosial ekonomi rendah lebih tinggi perencanaan kariernya dibandingkan dengan perencanaan karier siswa dari status sosial ekonomi sedang.

Hasil penelitian juga diketahui bahwa perencanaan karier siswa dari status sosial ekonomi tinggi, sedang, dan rendah tidak berbeda.Artinya, antara siswa dari status sosial ekonomi tinggi, sedang dan rendah sama-sama memiliki perencanaan karier yang baik.Hasil penelitian Kharisma (2015) menunjukkan bahwa terdapat pengaruh positif status sosial ekonomi orangtua terhadap minat melanjutkan pendidikan ke Perguruan Tinggi pada siswa kelas XII.Hasil penelitian Triastuti (2015) menunjukkan bahwa terdapat pengaruh yang signifikan bimbingan karier di sekolah dan status sosial ekonomi orangtua terhadap pemilihan karier. Berdasarkan hasil penelitian di atas, diketahui bahwa status sosial ekonomi orangtua berkontribusi terhadap pilihan karier siswa, hal yang wajar ada perubahan siswa dari status sosial ekonomi rendah lebih tinggi dalam hal perencanaan karier bila dibandingkan dengan siswa yang dari status sosial ekonomi tinggi dan sedang, karena beberapa alasan misalnya karena siswa ingin meningkatkan status sosial ekonomi keluarga, mengangkat derajat orangtua, tentu siswa dengan serius merencankan karier bila dibandingkan dengan siswa yang dari status sosial ekonomi sedang.

Sedangkan siswa dari status sosial ekonomi tinggi lebih tinggi perencanaan kariernya bila dibandingkan dengan siswa yang dari status sosial ekonomi sedang. Ini hal yang wajar siswa dari status sosial ekonomi tinggi tentu dapat merencanakan karier dengan baik, karena diketahui bahwa siswa tidak memikirkan biaya pendidikan terkait dengan karier yang diinginkan, siswa bisa berkonsultasi dengan orangtua mengenai karier yang diinginkan, serta orangtua dapat berkonsultasi dengan guru bimbingan dan konseling terkait dengan perencanaan karier anaknya. Bila dibandingkan siswa dari status sosial ekonomi tinggi dan sedang tentu berbeda dalam segi perencanaan kariernya. Faktor lain diduga perbedaan perencanaan karier siswa tersebut karena adanya pengaruh budaya, SMA Negeri 7 Padang siswa-siswinya rata-rata berlatar belakang budaya Minangkabau, diketahui bahwa didalam budaya Minangkabau anak laki-laki memiliki tanggung jawab yang tinggi terhadap keluarga. Diduga hal inilah yang mempengaruhi perencanaan karier siswa laki-laki dari status sosial ekonomi rendah lebih tinggi perencanaan kariernya bila dibandingkan dengan siswa dari status sosial ekonomi sedang.

2. Perbedaan Perencanaan Karier Siswa Ditinjau dari Jenis Kelamin

Berdasarkan hasil analisis deskriptif menunjukkan bahwa perencanaan karier siswa laki-laki dan perempuan sama-sama berada pada kategori tinggi (T).Jika dilihat berdasarkan rata-rata perencanaan karier siswa laki-laki lebih tinggi dibandingkan perencanaan karier siswa perempuan, namun tidak berbeda secara signifikan. Artinya antara siswa laki-laki dan perempuan sama-sama memiliki perencanaan karier yang baik untuk masa depan. Hasil penelitian ini sesuai dengan hasil penelitian Whitmarsh (2012) menunjukkan bahwa pria dan wanita lebih banyak kebersamaan dari pada perbedaan.Artinya antara laki-laki dan perempuan tidak banyak perbedaan.

Di samping itu ada faktor lain Menurut Hyde (dalam Santrock 2007:233) "perbedaan gender hampir tidak ada atau bahkan tidak ada sama sekali", dan Men Are from Mars, Women Are from Venus dan Debora Tannen (dalam Santrock 2007:233) "Perempuan dan lakilaki memiliki faktor-faktor psikologis yang sama". Selanjutnya hasil penelitian Correll (2001) mengemukakan bahwa perbedaan jenis kelamin dipengaruhi oleh budaya.Hal inilah yang diduga menjadi penyebab tidak berbedanya antara laki-laki dan perempuan dalam hal perencanaan karier.

\section{Perbedaan Perencanaan Karier Siswa Ditinjau dari Jurusan}

Hasil analisis deskriptif menunjukkan bahwa perencanaan karier siswa jurusan IPA dan IPS secara keseluruhan berada pada kategori tinggi (T).Jika dilihat dari rata-rata masing-masing jurusan, siswa jurusan IPA memiliki rata-rata tinggi dibandingkan dengan siswa jurusan IPS.Namun, tidak berbeda secara signifikan.Hal ini menunjukkan bahwa siswa jurusan IPA dan IPS memiliki perencanaan karier yang baik, hal ini menandakan bahwa siswa sudah mempunyai tujuan rencana karier yang baik kedepan.Khususnya terkait dengan karier yang akan digeluti nantinya.

Secara lebih rinci dapat dilihat dari masingmasing sub variabel masih ada sub variabel yang tergolong rendah dibandingkan dengan sub variabel lainnya, yaitu pengetahuan tentang dunia kerja. Hal ini menunjukkan bahwa pencapaian siswa dalam merencanakan karier belum maksimal. Berdasarkan hasil temuan ini dapat kiranya ada kerja sama dari berbagai pihak khususnya guru bimbingan dan konseling/konselor 
dalam membantu siswa merencanakan karier yang sesuai dengan kondisi diri dan karier yang diinginkan.

Selanjutnya, temuan penelitian menunjukkan tidak terdapat perbedaan perencanaan karier siswa jurusan IPA dan IPS. Hal ini diduga ada faktor lain yang berpengaruh terhadap perencanaan karier siswa seperti sistem pendidikan dan implementasi kurikulum saat ini. Penempatan siswa pada jurusan tertentu telah berdasarkan pertimbangan yang matang. Sebagaimana yang tertera berdasarkan Peraturan Menteri Pendidikan dan Kebudayaan Republik Indonesia Nomor 59 Tahun 2014 tentang kurikulum Sekolah Menengah Atas/Madrasah Aliyah bahwa Kurikulum Sekolah Menengah Atas (SMA) telah dirancang untuk memberikan kesempatan kepada peserta didik berdasarkan minat mereka.

Kelompok peminatan terdiri dari kelompok Matematika dan Ilmu Pengetahuan Alam (MIPA), Ilmu Pengetahuan Sosial (IPS).Jadi, dalam hal pemilihan jurusan pada siswa berdasarkan ketentuan kelompok peminatan yaitu mengacu pada nilai ujian nasional, potensi dasar, kecerdasan, hasil tes penempatan, tes bakat, dan minat.Hal tersebut sebagai dasar pertimbangan dalam menetapkan peminatan/jurusan bagi siswa.

Meskipun masih ada pandangan bahwa jurusan IPA nomor satu dan IPS nomor dua. Hal tersebut keliru, belum ada jaminan bahwa siswa jurusan IPA masa depan kariernya lebih cerah. Demikian juga sebaliknya, bukan berarti siswa jurusan IPS masa depan kariernya akan suram. Kedua jurusan tersebut sebenarnya tidak lebih dari upaya pengelompokkan ilmu pengetahuan, bukan dua hal yang berbeda ketinggiannya.

4. Perbedaan Perencanaan Karier Siswa Ditinjau dari Interaksi Variabel Status Sosial Ekonomi, Jenis Kelamin, dan Jurusan

Berdasarkan hasil penelitian yang telah diuraikan sebelumnya, bahwa perencanaan karier siswa ditinjau dari status sosial ekonomi, jenis kelamin, dan jurusan tergolong dalam kategori tinggi (T).Artinya, secara umum siswa telah memiliki perencanaan karier yang baik. Namun, jika dilihat dari hasil interaksi status sosial ekonomi, jenis kelamin, dan jurusan, tidak menunjukkan adanya interaksi yang signifikan dalam perencanaan karier siswa, maka dapat disimpulkan bahwa kombinasi antara variabel status sosial ekonomi, jenis kelamin, dan jurusan tidak memiliki interaksi dalam menjelaskan perencanaan karier.

Hal tersebut diduga disebabkan banyaknya faktorfaktor yang mempengaruhi perencanaan karier, artinya tidak hanya status sosial ekonomi, jenis kelamin, dan jurusan yang mempengaruhi perencanaan karier, tetapi masih banyak faktor lain yang dapat mempengaruhi perencanaan karier siswa, antara lain faktor nilai-nilai kehidupan, keadaan jasmani, pergaulan teman sebaya, orangtua, dan sebagainya. Super (dalam Sharf 1992:121) mengemukakan faktor-faktor yang mempengaruhi perencanaan karier yaitu values, interests, intelligence, ability, and special aptitudes.Hasil Penelitian Aminnurrohim (2014) mengemukakan bahwa banyak faktor yang menghambat perencanaan karier siswa yang paling banyak ditemui adalah dari faktor eksternal yaitu kondisi sekolah. Selanjutnya, dari hasil penelitian ini kiranya dapat dijadikan rujukan bagi guru bimbingan dan konseling/konselor sekolah dalam melaksanakan pelayanan bimbingan dan konseling disekolah, berdasarkan data yang diperoleh dapat dijadikan sebagai arah dalam menentukan prioritas kebutuhan, sasaran pelaksanaan pelayanan bimbingan karier bagi siswa.

\section{KESIMPULAN}

Berdasarkan temuan dan pembahasan hasil penelitian, maka dapat diambil kesimpulan sebagai berikut.

1. Perencanaan karier siswa ditinjau dari status sosial ekonomi, jenis kelamin, dan jurusan berada pada kategori tinggi.

2. Tidak terdapat perbedaan yang signifikan perencanaan karier siswa ditinjau dari status sosial ekonomi. Namun, secara rata-rata perencanaan karier siswa dari status sosial ekonomi tinggi, dan rendah lebih tinggi dibandingkan siswa dari status sosial ekonomi sedang.

3. Tidak terdapat perbedaan yang signifikan perencanaan karier siswa ditinjau dari jenis kelamin laki-laki dan perempuan. Namun, secara rata-rata perencanaan karier siswa laki-laki lebih tinggi dibandingkan siswa perempuan.

4. Tidak terdapat perbedaan yang signifikan perencanaan karier siswa jurusan IPA dan IPS. Namun, secara rata-rata perencanaan karier siswa jurusan IPA lebih lebih tinggi dibandingkan siswa jurusan IPS.

5. Tidak terdapat interaksi antar variabel status sosial ekonomi, jenis kelamin, dan jurusan dalam menjelaskan perencanaan karier siswa.

\section{SARAN}

Berdasarkan hasil penelitian ini beberapa saran yang dapat diajukan sebagai berikut.

1. Bagi Siswa

Diharapkan untuk aktif mengikuti pelayanan bimbingan konseling sehingga siswa dapat mengkonsultasikan berbagai hal terkait dengan tugas perkembangannya, khususnya dalam hal perencanaan karier.

2. Guru BK

Disarankan untuk meningkatkan pelaksananaan program pelayanan bimbingan konseling di sekolah terkait dengan perencanaan karier siswa.

3. Bagi Kepala Sekolah

Diharapkan untuk dapat bekerjasama dengan guru bimbingan dan konseling/konselor dalam membantu siswa mencapai tugas perkembangannya, khususnya terkait dengan perencanaan karier siswa.

4. Peneliti lainnya

Perlu dilakukan penelitian yang sejenis, akan tetapi dilatarbelakangi oleh latar belakang ataupun variabel yang berbeda agar dapat membandingkan temuan dari penelitian ini serta dapat memperdalam, memperjelas, dan memberikan temuan yang terbaru terkait dengan perencanaan karier siswa. 


\section{DAFTAR RUJUKAN}

Ahmad, R. 2013. Dasar-dasar Bimbingan dan Konseling. Padang: UNP Press.

Aminnurrohim, A.,W., Saraswati, S., \& Kurniawan, K. 2014. Survei Faktor-faktor Penghambat Perencanaan Karier.Journal. Indonesia Journal Guidance and Counseling: Theory and Application (Online), Vol. 3, No.2. (http://journal.unnes.ac.id/sju/index.php/jbk, diakses 24 Juli 2016).

Correl, S. J. 2014. Gender and the Carrer Choice Process.Journal of Sociology, Vol. 106.1691-1730 (http://www.jstor.org/stable/10.1086/321299, diakses 24 Juli 2016).

Brown, D \& associates. 2002. Career choice and development.Jossey-Bass business \& management series.

Hoffman, M. C. 2007. Career Development Interventions with Low Socio-economic Status Students. Counselor Education Master' s Theses. Paper 52.The College at Brockport: State University of New York.

Hurlock, E. B. 1996. Psikologi Perkembangan: Suatu pendekatan sepanjang rentang kehidupan. Terjemahan oleh Istiwidayanti (Edisi Kelima) Jakarta: Erlangga.

Kharisma, N., \& Latifah, L. 2015. Pengaruh Motivasi, Prestasi Belajar, Status Sosial Ekonomi Orangtua dan Lingkungan Teman Sebaya terhadap Minat Melanjutkan Pendidikan ke Perguruan Tinggi pada Siswa Kelas XII Kompetensi Keahlian Akuntasnsi di SMA Negeri Se-Kota Semarang Tahun Ajaran 2014/2015. Journal Economi Education Analysis.(Online), Vol. 4, No. 3.(http://journal.unnes.ac.id/sju/index.php/eeaj diakses 24 Juli 2016).

Whitmarsh., L., W., \& Keyser., D. 2012. Gender Similarity or Gender Difference?Contemporary Women's and Men's Career Pattern. Journal The Carrer Development Quarterly. (Online), Vol. 60, No1.(http://search.proquest.com/index, diakses 27 Juli 2016).

Peraturan Menteri Pendidikan dan Kebudayaan Republik Indonesia Nomor 59 tahun 2014 tentang Kurikulum 2013 Sekolah -Menengah Atas/Madrasah Aliyah. Jakarta: Menteri Pendidikan dan Kebudayaan Indonesia.

Santrock, J. W. 2007. Remaja (Edisi 11 Jilid 1).Terjemahan oleh Benedictine Widyasinta. Jakarta: Erlangga.

Sharf, R. S. 1992.Applying Career Development Theory to Counseling. Pacific Grove, California. University of Delaware: Brooks/Cole Publishing Company.

Sharf, R. S. 2010.Applying Career Development Theory to Counseling. Pacific Grove, California. University of Delaware: Brooks/Cole Cengage Learning.

Triastuti \& Fransisca, M. 2015.Pengaruh Bimbingan Karier di Sekolah dan Status Sosial Ekonomi Orang Tua Pada Pilihan Karier Siswa.Journal FKIP-Universitas Katolik Widya Mandala Madiun.(Online), Vol. 2 No. 2.
Undang-Undang Reublik Indonesia Nomor 20.Tahun 2003 tentang Sistem Pendidikan nasional.Jakarta: Sekretariat Jenderal Departemen Pendidikan Nasional.

Winkel, W. S., \& Hastuti, M. M. S. 2013.Bimbingan dan Konseling di Institusi Pendidikan. Yogyakarta: Media Abadi.

Yusuf, A. M. 2002. Kiat Sukses dalam Karier. Jakarta: Ghalia Indonesia.

Zen, M. 2012. "Faktor-faktor Dominan yang Berpengaruh dalam Perencanaan Arah Karier Studi pada Siswa SMA Negeri Kota Pariaman".Disertasi tidak diterbitkan. Padang: Program Pascasarjana UNP.). 